果都表明水稻叶片吸收和向根系运輸氧气有着很大 的潛在能力, 只要有部分叶片暴露在空气中它就可 吸收大量氧气供应其它部分。在生产实践中常看到 当水稳等植物受到淹涝时, 只要有部分叶尖露出水 面就不致使整株受到空息，其原因可能就在于此。

在水中发芽的水稻, 由于缺忈氧气, 幼芽鞘伸

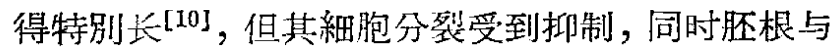
幼叶的生长也显著受阻 ${ }^{[11]}$ 。可是胚芽鞘尖一旦伸出 水面这种情况立刻改变; 芽鞘停止伸长, 胚根、幼叶 迅速生长。我們的試驗証实了芽鞘尖露出水 面 后, 它能吸收大量的氧气来供給淹水的下部(表 3 )。因 此在水稻青秧时 (尤其是水秧田), 避免长时間的将 幼芽淹在水下，对防止単积、培青壮秧来說是重要 的一环。

表 3 水稻胚芽鞘的运氧作用

\begin{tabular}{|c|c|}
\hline 处 & 20 株总耗 $\mathrm{O}_{2}$ 量 ( $\mu \mathrm{l} /$ 小时) \\
\hline 芽䩗在水面下 $1 \mathrm{~mm}$ & 13 \\
\hline 芽鞘伸出水面 $1 \mathrm{~mm}$ & 40 \\
\hline $\begin{array}{l}3 \mathrm{~mm} \text { 长的离体芽鞘 } \\
\text { 尖在空气中 }\end{array}$ & 8 \\
\hline
\end{tabular}

綜上所述, 沼生的水稳和一些早生植物的水培 幼苗暴露在空气中的茎叶都能向淹在水下的部分及 根系輸迕氧气。稗草与水稻較早生植物向根系輸迢 氧气的比例大, 这无疑是它在系統发育与个体发育 中长期适应沿生环境的結果。在水培条件下沼生与 旱生植物的根系都处在缺氧环境中，茎叶向根采供 应的氧气对根系进行有氯呼吸、維持正常的吸收与 合成功能一定起着重要作用。

[1] Van Raalte M. H., Ann. Jard. Bot. Biutenzorg, 50, 99-113 (1940).

[2] 相見灵三，日作記，29 (1)，51-54 (1960)。

[3] Barber D. A., Ébert M., Evans N. T. S., J. Exp. Bot., 13, 397-403 (1962).

[4] Brown R., Annals of Bot., 11, 417-437 (1947).

[5]山田登、树田吉男、长田明头、猪山純一即, 日作 記, $22(3,4), 55-56(1954) 。$

[6] 有門博树, 日作記, 28, 1-3 (1959)。

[7] Солдатенков С. В., Чжао Сянь-дуан, Физиол. Pacr., 8 (4), 386-394 (1961).

[8]娄成后、白克智、朱茂山, 实驗生物学报, $8(3,4)$, $566-575$ (1963)。

[9] 杰姆斯, 《植物的㭔吸作用》, 科学出版社出版, 第 91-109 頁, 1959。

[10] 娄成后、薛应龙、筒龙飞, 中国科学, 2, 49-68 (1951)。

[11] 朱 溦、湯凩松，植物学报，8, 202-214 (1959)。

\title{
高等植物幼苗茎叶向根系运輸氧气的研究
}

\section{II. 莝叶向根系运氧的途径与状态}

\author{
类成后白克智殷蔚薏
}

（中国科学院植物研究所·北京物业大学）

对于植物体队氧气沄輸的途径和状态有两种不 同的意見 ${ }^{[1]}{ }_{0}$ van Raalte ${ }^{[2]}$ 、山田登等 ${ }^{[3]}$ 发現水稻根采 的空气閏隙中氧气的浓度有自上而下降低的趋势， 因而訩为氧气是由相互連通的空气閒隙从茎叶扩散 下运到根部的。Barber ${ }^{[+]}$等用放射性 $\mathrm{O}^{15}$ 所得的結
果支持上述覌点。Brown ${ }^{[5]}$ 、相見 ${ }^{[6]}$ 、Солдатенков 等 ${ }^{[7]}$ 則訩为宾气間隙在組織中所占的比例很小，氧 气在其中的扩散速度很慢, 强調茎叶对根系有 “主 动”运氧的作用。Рубин ${ }^{[8]}$ 曾提出氯气可能形成过 氧化物向組織內部轉移。Ullrich ${ }^{[9]}$ 訩为㖕皮部的过 
氧化物酶亲統可以分解結合态氧，供气态氧难于达 到的彰皮部組織呼吸之用。

若茎叶与根系䦎的氧气运輸是以气态通过扩散 的方式下运, 則运輸量应与根系空气閒隙所占的比 例有关; 若氧气以結合态或溶解态下运，則物稹运 輸最活跃的維管束系統应是主要通道。本文是报导 从这两方面检驗的結果。

\section{一、根系的空气間隙与氧气下运的关系}

根系的空气間吵是用我們設計的比 重法 測 量 的 ${ }^{[10]}$ 。茎叶向根系的运氧則用比重呼吸計測量 ${ }^{[11]}$ 。 測量水培的与旱生的（根系在湿度飽和的空气中培 养)水稻与踠豆幼苗根系的空气間隙与氧气下运量， 結果列于表 1 。水槄較踠豆根系的空气間隙大得多。 氧气下运的比例也較大。同种植物中水培苗的空气 閒隙与氧气下运比例較旱生苗大。从水下根系由茎 叶所得氧气为同一根添在空气中吸氧的百分数中， 也可以看出水稻苗大于楁豆苗、水培苗大于旱生苗 的情况。上述結果可以解释为：水培苗的根系一直 生长在氧气供应困难的静水中，皮层的內部特別缺 氯，其中某些細胞的解体造成了較大的裂生間䏚,增 大了茎叶向根系运氧的通道; 早生苗在氧气充足的 环境里培养，只是在測量时根系才处于缺氧的水下， 原来的間隙既小，氧气下运量世少。水稻較踠豆的 宾气間隙大、氧气下运量多, 大約是它能生长在沼 生环境里的主要原因。

表 1

\begin{tabular}{|c|c|c|c|c|}
\hline 作 物 & 水 & 稻 & 踠 & 馬 \\
\hline 項 目 & 水培苗 & 旱生苗 & 水培苗 & 旱生苗 \\
\hline $\begin{array}{l}\text { 棍系空气間隙的\% } \\
\text { (距根尖 } 2-3 \mathrm{~cm} \text { 处) }\end{array}$ & $30-40$ & $10-20$ & $4-5$ & $>1$ \\
\hline $\begin{array}{l}\text { 水下根系由莰叶得到的 } \\
\text { 氧气为根係在空气中吸 } \\
\text { 氧量的\% }\end{array}$ & $50-80$ & $30-40$ & $50-70$ & $20-30$ \\
\hline $\begin{array}{l}\text { 茎叶向其水下根系翰䢪 } \\
\text { 的氧气占叶片总吸氧舅 } \\
\text { 的\% }\end{array}$ & $30-60$ & $10-20$ & $20-30$ & $5-10$ \\
\hline
\end{tabular}

Barber 等 ${ }^{[12]}$ 研究放射性 $\mathrm{O}^{15}$ 通过大麦与水稻幼 苗茎旪向根系的运輸，扞曾检驗根系空气間䏚的比 例与 $\mathrm{O}^{15}$ 下运的关系, 发現大麦根的空气間隙小于 $1 \%$ ，水稻根則为 $5-30 \%$ ，大麦根中的 $0^{15}$ 世較水
稻少得多。从表 1 的結果中可以更明显地看出空气 間隙的大小与氧气下运量的正相关。

二、組織的空气間隙充水、环割根系皮层或切 䉼維管束对氧气下运的影响

（1）将水稻与小麦幼苗于員空下渗入蒸 餾 水， 然后用比重呼吸計测量其呼吸强度。由比較充水苗 与正常苗剪断水下根柔前后茎叶吸藋量的美异，检 查充水对氧气下运的影响, 結果見表 2 。正常植株 (对照)切去根系后吸氧量明鼠降低; 而充水植株切

表 2

\begin{tabular}{|c|c|c|c|}
\hline & 处 理 & $\begin{array}{l}\text { 带根的茎叶吸 } \\
\text { 氧 } \mu \mathrm{l} / \text { 株/小时 }\end{array}$ & 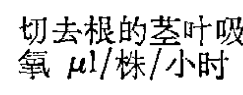 \\
\hline 水 & 売 水 & 11 & 10 \\
\hline 桷 & 对 照 & 22 & 12 \\
\hline 小 & 充 水 & 30 & 30 \\
\hline 麦 & 对 照 & 38 & 31 \\
\hline
\end{tabular}

根前后茎叶的吸氧量几乎沟有差异。这表明空气間 吵被水堵塞之后氯气郎不再向水下根系运輸。

（2）取生长 15 天的踠豆幼苗在根基部将外围 的皮层环割, 只保留中柱的維管束使茎叶与根系根 連(見图 1b); 或切断維管束保留皮层（見图 1c)，手 术后用比重呼吸計測量其吸氧量, 結果見表 3 。环 割皮层的植株在切去水下根系前后茎叶吸氧量的差
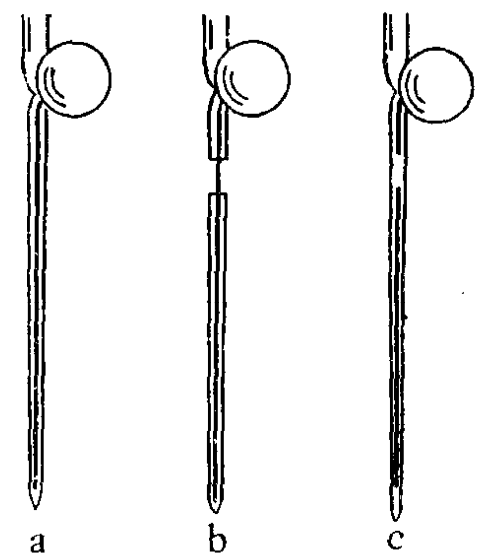

图 1 豆类幼苗切割处理示意图 a. 对照，不加切割 b. 环割皮层 c. 切断(或穿刺)中柱的維管束 
异极小, 对照植株切去根系后吸氧量明显降低, 这 表明环割皮层后茎叶吸收的氧气几乎完全不能下运 到根系。切阯維管束的植株剪根后吸氯量降低的比

表 3

\begin{tabular}{|c|c|c|}
\hline 处 & $\begin{array}{l}\text { 带根的茎叶吸 } \\
\text { 氧 } \mu 1 / \text { 株/小时 }\end{array}$ & $\begin{array}{l}\text { 切去根的茎叶吸 } \\
\text { 氧 } \mu \mathrm{I} / \text { 株/小时 }\end{array}$ \\
\hline 环割皮层 & 250 & 245 \\
\hline 切断維管束 & 220 & 180 \\
\hline 对 & 255 & 195 \\
\hline
\end{tabular}

例与对照相似, 說明切断維管束抹未影响茎叶向根 系迋氧。

最近崔郁英与邹琦切割歪豆幼苗胚根 的試 驗 (待发表資料)也証明: 当胚根基部的皮层被环割后 (如图 $1 \mathrm{~b}$ )，若放在通气的条件下(湿潤空气或不断. 通气的水中), 則根尖的生长接近正常; 但若肧根从 环割处起全部浸没在静水中时，根尖的生长完全停 滞，与缺氧的处理相似。

所有上述的試驗結果都支持氧气运迕的被动机 制。氧气是通过茎叶皮层的空气閒隙以气态沿浓差 䠌度扩散到根部的。

Brown 等 ${ }^{[5-7]}$ 訩为, 茎叶主动运氧的主要根据 是：将植物茎叶与根系分別密封在上下二室內，若 下室中充以氮气或氢气，上室的氧气可以通过茎部 传导到根部; 但切除茎叶后根系不能通过暴露在上 室中的切口吸收氧气。我們用比重呼吸計測 量 时, 当切去叶片后茎部暴露在气相中的部分过短时，水 下根系也不能吸收气相中的氧气。但这一現象不足 以作为茎叶主动运氧的証据。大家知道, 氧气在水 里的溶解度很低, 扩散速率很慢, 因而一层水膜可 能严重阻碍气态氯的通过。茎基部的切口不断有伤 流外湓, 复盖在切口表面的伤流洨可能成为氧气向
根部传导的主要障碍。这已由 Takao 等 ${ }^{[13]}$ 的試驗 所証明, 多种植物組織有微量水膜复盖时師使其吸 氧速率大大降低，作者訩为是組織的空气間隙被水 堵塞，組織內部不能得到充分氧气之故。

最近, Солдатенков 等 ${ }^{[14]}$ 报导, 根系密封在儛 气中的荣豆植株当用湜伤法环剥茎部后，根系師不 能再从叶片获得氧气，作者据此訩为氧气下运的途 径是喡皮部。这一結論似不够全面，因湯伤既堵塞 了彰皮部，同时也破坏了皮窟的空气閒隙。

氯气形成过氧化物等結合态或以溶解态在植物 体內运輸的可能性是存在的，但从本試驗的結果来 看, 茎叶向根采远迕的大量氮气是以气态沿組織中 的空气間隙下运的。

[1] 戶荻义次等編, 《作物的生理生态》, 科学出版社出 版，第 94一99頁，1962。

[2] van Raalte M. H., Ann. Jard. Bot. Biutenzorg, 50, 99-113 (1940).

[3]山田登、树田吉男、长田明夫、猪山純一郳，日作 記, $22(3,4) ， 55-56$ (1954)。

[4] Barber D. A., Ebert M., Evans N. T. S., J. Exp. Bot., 13, 397-403 (1962).

[5] Brown R., Annals of Bot., 11, 417-437 (1947).

[6] 相見灵三，日作記，29(1)，51一54 (1960)。

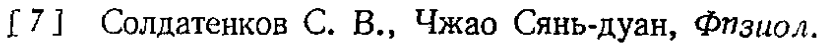
Pact., 8 (4), 386-394 (1961).

[8] Рубин Б. А., Логинова Л. Н.; Успех Совр. Биол., 55 (3), 465-480 (1963).

[9] Ullrich W., Planta, 57, 402-429 (1961).

[10] 娄成后、薛应龙、閻龙飞，中国科学，2，49-68 (1951)。

[11] 娄成后、白克智、柂茂山, 实驗生物学报, $8(3,4)$, 566 -575 (1963)。

[12] 殷蔚薏, 植物生理学通訊, 3, 55 (1963)。

[13] Takao O., Howell R. W., Plant Physiol., 35, 184-188 (1960).

[14] Солдатенков С. В., Чиркова Т. В., Физиол. Pact., 10, 535-543 (1963). 